\title{
PENGARUH KECERDASAN INTRAPERSONAL DAN KEMANDIRIAN BELAJAR TERHADAP KEMAMPUAN BERPIKIR KREATIF PADA PELAJARAN MATEMATIKA
}

\author{
Maratusyolihat $^{1}$, Nida Adillah' ${ }^{2}$, Miftahul Ulfah ${ }^{3}$ \\ STAI. KH. Abdul Kabier Serang \\ Email : maratusyolihatihat@gmail.com ${ }^{1}$, nidaadillah90@gmail.com², \\ miftahululfh88@gmail.com ${ }^{3}$
}

\begin{abstract}
This study aims to determine the effect of intrapersonal intelligence and learning independence on the ability to think creatively in mathematics. Research place at MTs Serang district. This research method uses a survey method, with a sample of 83 people. The sampling technique uses multi-stage sampling. Collecting data using essay tests and questionnaires. Hypothesis testing using path analysis (path analysis). The results of the study concluded that there was a significant influence of intrapersonal intelligence and learning independence on the ability to think creatively in mathematics. More effectively improve the ability to think creatively is done by awakening the independence of learning first in mathematics. So that students easily grasp the material being taught and students will be more motivated and happy in learning because they are already familiar with the learning system.
\end{abstract}

Keywords : Intrapersonal intelligence, , Learning Independence, and Creative thinking skills

Abstrak: Penelitian ini bertujuan untuk mengetahui pengaruh kecerdasan intrapersonal dan kemandirian belajar terhadap kemampuan berpikir kreatif pada pelajaran matematika. Tempat penelitian di MTs kabupaten Serang. Metode penelitian ini menggunakan metode survey, dengan jumlah sampel 83 orang. Tekhnik sampling menggunakan multi stage sampling. Pengumpulan data menggunakan tes essay dan angket. Uji hipotesis menggunakan analisis jalur (path analysis). Hasil penelitian menyimpulkan terdapat pengaruh yang signifikan kecerdasan intrapersonal dan kemandirian belajar terhadap kemampuan berpikir kreatif pada pelajaran matematika. Lebih efektif meningkatkan kemampuan berpikir kreatif dilakukan dengan membangkitkan kemandirian belajarnya terlebih dahulu pada mata pelajaran matematika. Sehingga siswa mudah menangkap materi yang diajarkan dan siswa akan lebih termotivasi serta senang dalam belajar karena sudah terbiasa dengan system pembelajarannya.

Kata Kunci : Kecerdasan Intrapersonal, Kemandirian Belajar, dan Kemampuan Berpikir Kreatif 


\section{PENDAHULUAN}

Kemajuan suatu bangsa ditentukan kualitas pendidikan yang menghasilkan sumber daya manusia. Kualitas sumber daya manusia dilihat dari kualitas lulusan lembaga pendidikan, serta dapat berkompentensi dengan negaranegara lain. Secara umum kualitas sumber daya manusia Indonesia masih rendah. Rendahnya kualitas sumber daya manusia sebagian diakibatkan kualitas pendidikan masih rendah. Kualitas pendidikan rendah sebagian akibat karena rendahnya kemampuan pemahaman matematika.

Pemerintah melalui Dinas Pendidikan memegang peranan dalam upaya peningkatan kualitas pendidikan nasional tersebut. Salah satu upaya tersebut adalah dengan meningkatkan mutu pembelajaran matematika. Matematika adalah ilmu universal yang mempunyai peranan penting dalam berbagai disiplin ilmu dan memajukan daya pikir manusia. Matematika merupakan ilmu yang mendasari perkembangan teknologi modern dan mempunyai peranan penting dalam berbagai disiplin ilmu. ${ }^{1}$

Rendahnya kemampuan peserta didik dalam memahami dan memaknai matematika sudah dirasakan sebagai masalah yang cukup pelik dalam pengajaran matematika di sekolah. Permasalahan tersebut muncul cukup lama dan terabaikan karena kebanyakan guru matematika dalam kegiatan pembelajaran berkonsentrasi mengejar nilai Ujian Akhir Nasional (UAN). Oleh karena itu, kegiatan pembelajaran biasanya difokuskan melatih peserta didik terampil dalam menjawab soal matematika, sehingga penguasaan dan pemahaman matematika peserta didik terabaikan.

Pemahaman diri pribadi ini berkembang sejalan dengan perubahan yang terjadi dalam hidup. Manusia tidak terlahir dengan pemahaman tentang dirinya, tetapi perilaku manusia selama ini memainkan peranan penting dalam membangun pemahaman diri pribadi. Pengarahan diri merupakan daya yang memberikan arah dan tanggung jawab terhadap konsekuensi perilakunya, yang terdiri atas kurang percaya diri, dan kurang mampu mengendalikan diri.

Kecerdasan intrapersonal merupakan kecerdasan seseorang yang mampu memahami diri sendiri, mengetahui kelemahan-kelemahan yang ada pada dirinya sendiri. Sehingga dapat memotivasi pada diri sendiri. Biasanya orang yang mempunyai skor tinggi dalam factor-faktor kecerdasan intrapersonal akan digambarkan sebagai seseorang yang merasa nyaman pada dirinya sendiri, puas dan berpikiran positif karena apa yang dilakukannya itu atas jerih payahnya sendiri.

Kecerdasan interpersonal yaitu kecerdasan dalam memahami proses belajar mengajar dengan berinteraksi dengan orang lain secara efektif. ${ }^{2}$ Kecerdasan intrapersonal memiliki gambaran yang akurat tentang diri sendiri, kesadaran terhadap suasana hati dan batin, motivasi, emosi, keinginan, kemampuan untuk mendisiplinkan diri, dan pemahaman diri. Siswa memiliki kecerdasan intrapersonal kuat diharapkan mampu menguasai materi untuk diri sendiri tanpa harus selalu diarahkan dari orang lain. Aktivitas yang sesuai dengan kecerdasan intrapersonal adalah bermain peran, strategi dalam kerjasama, bekerja

${ }^{1}$ Fajriyah dkk, "Penerapan Strategi Pembelajaran Metakognitif terhadap Hasil Belajar Matematika", Edu Research, Jakarta: Unindra Press, Vol. 1: 2015, h. 169-195.

2 Syasmita dkk, "The Influence of Ethno Pedagogy Approach and Interpersonal Intelligence on the Results of Civic Education Learning in Pelangi Elementary school Medan", BirLE Journal. 2 (4): 2019, h. 603. 
secara kooperatif, refleksi perkembangan prestasi pada diri sendiri, pemberdayaan diri sendiri, menjalankan tugas pribadi, dan menetapkan tujuan sendiri. Kecerdasan intrapersonal kuat akan meningkatkan motivasi dan menstimulasi pemikiran yang kreatif.

Apabila kecerdasan interpersonal tidak dimanfaatkan dengan baik maka dapat mempengaruhi hasil belajar siswa menjadi rendah. Pada kecerdasan intrapersonal banyak siswa yang tidak dapat mengendalikan kecerdasan intrapersonal yang mereka miliki seperti kurang mengenali diri sendiri, kurang mengetahui apa yang diinginkan dan mengetahui apa yang penting. ${ }^{3}$

Aktivitas tambahan yang bertujuan untuk meningkatkan kecerdasan intrapersonal siswa adalah melakukan praktikum reaksi reduksi oksidasi dan penyelesaian tugas secara mandiri. Aspek kemampuan diri dapat dilihat dari kemampuan siswa melakukan praktikum. Siswa mampu melihat dan mengimplementasikan informasi berdasarkan fakta tentang suatu konsep. Teori yang sudah didapat dikelas dibuktikan dengan praktikum di laboratorium. Kemampuan praktikum siswa dibagi menjadi kemampuan sebelum praktikum, selama praktikum, laporan sementara, dan akhir praktikum.

Selain kecerdasan intrapersonal, keberhasilan siswa dalam belajar juga dipengaruhi oleh faktor lain yang juga tidak kalah penting, yaitu kemandirian belajar. Kemandirian belajar juga berperan penting dalam keberhasilan siswa, karena kemandirian belajar merupakan dorongan yang timbul dari diri siswa secara sadar atau tidak sadar yang bisa muncul dari dalam diri sendiri untuk melakukan tindakan dengan tujuan tertentu secara mandiri. Kemandirian belajar adalah usaha-usaha yang menyebabkan seseorang atau kelompok orang bergerak melakukan sesuatu karena ingin mencapai tujuan yang dikehendaki. Namun pada intinya bahwa kemandirian belajar merupakan kondisi psikologis yang mendorong seseorang untuk melakukan sesuatu.

Kemampuan kemandirian belajar matematika juga penting yang harus dimiliki seorang siswa. Banyak siswa yang memiliki kemampuan kemandirian yang cukup rendah akibatnya proses pembelajaran tidak dapat tercapai sesuai dengan apa yang ditargetkan. Apabila kemampuan kemandirian belajar tidak terpenuhi maka suatu pembelajaranpun tidak akan terlaksana dengan baik.

Kemandirian belajar adalah keahlian seorang siswa yang melakukan pembelajaran secara mandiri. Kemandirian belajar merupakan kemampuan yang dimiliki seorang siswa untuk berupaya menjadi mandiri dalam menggali informasi belajara selain sumber belajar yang diberikan oleh guru. ${ }^{4}$

Dari pernyataan atas dapat disimpulkan bahwa kemandirian belajar adalah suatu usaha serta kemampuan yang dimiliki oleh siswa yang dilakukan dalam aktivitas belajar dengan berupaya menjadi mandiri dalam menggali informasi serta memiliki motivasi sendiri dalam menguasai suatu materi tanpa adanya paksaan. Perkembangan dalam bidang teknologi pembelajaran menekankan pada pentingnya kemandirian dalam belajar. Peserta didik ditingkatkan perannya sehingga benar-benar menjadi subyek dalam proses pembelajaran. Mereka benarbenar dipandang sebagai individu yang sedang berusaha meningkatkan

\footnotetext{
${ }^{3}$ Muhammad Wadji dkk, "Hubungan Kecerdasan Naturalistik, Kecerdasan Interpersonal, dan Kecerdasan Intrapersonal dengan Hasil Belajar Biologi Siswa Kelas XI IPA SMA Negeri di Kota Makasar”, UNM Journal of Biological Education, Vol-2 (1), 2018.

${ }^{4}$ Fajriyah dkk, "Pengaruh kemandirian belajar siswa smp terhadap kemampuan penalaran matematis”, Journal On Education, 01(02), 2019, h. 288-296.
} 
kemampuannya melalui penguasaan berbagai keterampilan, pengetahuan, nilainilai dan sikap. Jadi kemandirian belajar merupakan prinsip yang sangat penting didalam interaksi belajar mengajar untuk mencapai tujuan pembelajaran yang telah ditentukan.

Kemajuan ilmu pengetahuan dan teknologi menuntut seseorang untuk dapat menguasai informasi dan pengetahuan. Kemampuan-kemampuan tersebut juga membutuhkan pemikiran yang kritis, sistematis, logis, dan kreatif. Oleh karena itu diperlukan suatu kemampuan memperoleh, memilih dan mengolah informasi melalui kemampuan berfikir kritis, sistematis, logis dan kreatif. Salah satu program pendidikan yang dapat mengembangkan kemampuan berfikir kritis, sistematis, logis, dan kreatif. Sehubungan dengan hal itu maka proses pembelajaran matematika di kelas sudah seharusnya dilakukan perubahan. Konsep matematika harus dibangun dengan pemahaman siswa itu sendiri. Hal yang harus dilakukan guru adalah bagaimana mendorong siswa untuk berfikir, bertanya, memecahkan masalah, mengemukakan ide, mendiskusikan ide bahkan menemukan sesuatu yang baru.

Mementingkan pemahaman daripada hanya mengingat prosedur, mementingkan membuat dugaan, penemuan dan pemecahan soal dan menjauhkan dari tekanan pada penemuan jawaban secara mekanis. Mengaitkan matematika, ide-ide dan aplikasinya dan tidak memperlakukan matematika sebagai kumpulan konsep dan prosedur yang terasingkan.

Kemampuan berpikir kreatif adalah kemampuan menganalisis sesuatu berdasarkan data atau informasi yang tersedia namun juga melahirkan konsepkonsep baru yang jauh lebih sempurna dan menentukan alternatif-alternatif dengan berbagai ide yang dapat digunakan untuk memecahkan permasalahannya. Dalam berpikir kreatif, seseorang akan melalui tahapan mensintesis ide-ide, juga melahirkan konsep-konsep baru yang jauh lebih sempurna dalam merencanakan penggunaan ide-ide, dan mengimplementasikan ide-ide tersebut sehingga menghasilkan sesuatu yang baru dan lebih sempurna.

Kemampuan berpikir kreatif adalah kemandirian berpendapat secara logis untuk mencari solusi permasalahan matematika berdasarkan konsep dan prosedur. ${ }^{5}$ Peserta didik mampu menemukan solusi masalah matematika dengan sudut pandang yang berbeda - beda. ${ }^{6}$ Perbedaan sudut pandang karena adanya perbedaan peserta didik dalam menerima rangsangan guru saat proses pembelajaran. ${ }^{7}$

Terdapat beberapa indikator berpikir kreatif peserta didik yaitu :

1) kelancaran dimana peserta didik dapat menghasilkan gagasan dalam jumlah banyak,

2) keluwesan, pada indikator ini peserta didik memberikan cara berbeda untuk menyelesaikan permasalahan dan mampu menyelesaikan masalah dengan sudut pandang yang berbeda,

\footnotetext{
${ }^{5}$ Hanipah, dkk, "Analisis Kemampuan Berpikir Kreatif Matematis Siswa MTs Pada Materi Lingkaran”, AKSIOMA: Jurnal Program Studi Pendidikan Matematika, 7(1). 2018.

${ }^{6}$ Munahefi dkk, "Analysis of Creative Mathematic Thinking Ability in Problem Based Learning Model Based on Self- Regulation Learning", Journal of Physics: Conference Series, 983(1), 2018, h. 1-5.

${ }^{7}$ Maharani, "Analisis Pengembangan Soal Tes Evaluasi Matematika Berbasis Kemampuan Berpikir Kreatif Untuk Siswa SMK pad Materi Geometri” AKSIOMA: Jurnal Program Studi Pendidikan Matematika, 6(3). 2017.
} 
3) keaslian dalam indikator tersebut peserta didik mampu menganalisis sendiri permasalahannya dengan cara baru,

4) keterperincian, peserta didik memberikan jawaban secara rinci dan detail, prosedur pengerjaan soal ditulis dengan jelas dan benar.

Pembelajaran matematika yang kurang bervariasi akan mempersulit perkembangan kemampuan berpikir kreatif. Kemampuan berpikir kreatif peserta didik dalam menyelesaikan tes masih sangat rendah. Jawaban yang diberikan cenderung monoton dan kurang bervariasi. Pada kenyataannya siswa tidak banyak terlibat dalam mengkontruksi pengetahuan yang dimilikinya, hanya menerima informasi yang disampaikan searah dari guru. Fenomena ini sebagai pemicu melemahnya berfikir kreatif matematis siswa, yang akhirnya akan berimbas pada kemampuan berfikir kreatif matematis siswa menjadi rendah. Hal ini menjadi tantangan bagi guru untuk terus menerus menciptakan suasana belajar yang lebih bermutu.

\section{PEMBAHASAN}

Matematika berasal dari Bahasa latin yaitu manthanein atau mathema yang berarti belajar atau hal yang dipelajari. Ciri utama matematika adalah pealaran deduktif, yaitu kebenaran sebelumnya sehingga kaitan antar konsep atau pernyataan dalam matematika bersifat konsisten. Pelajaran matematika merupakan pelajaran yang dipelajari dari jenjang dasar sampai dengan perguruan tinggi.

Matematika merupakan sebagai suatu bidang ilmu yang merupakan alat piker, berkomunikasi, alat untuk memecahkan berbagai persoalan praktis, yang unsur-unsur logika dan intuisi, analisis dan kontruksi, generalitas dan individualitas serta mempuanyai cabang antara lain aritmatika, aljabar, geometrid an analisis. Matematika juga merupakan representasi dari data, fakta dan fenomena dari alam semesta, melalui symbol-simbol yang kita kenal dengan angka dan huruf.

Pelaksanakan pembelajaran matematika memerlukan beberapa kecakapan guru untuk menentukan suatu strategi pembelajaran yang tepat, baik untuk materi maupun situasi dan kondisi pembelajaran. Sudah saatnya meninggalkan proses pembelajaran yang cenderung mengutamakan hapalan atau sekadar menemukan satu jawaban benar dari soal. Metode pembelajaran pendidikan Indonesia harus mulai beralih menjadi proses-proses pemikiran yang visioner, termasuk mengasah kemampuan cara berpikir kreatif dan inovatif. Hal ini diperlukan untuk menghadapi berbagai perkembangan teknologi dan ilmu pengetahuan.

Matematika sebagai media atau sarana dalam mendukung siswa mencapai suatu kompetensi yang diharapkan. ${ }^{8}$ Matematika adalah ilmu seni kreatif. Dalam disiplin matematika konsep-konsep yang mendasarinya diperoleh melalui penalaran dan kreatifitas sedangkan kebenaran akan konsep didasarkan atas kaidah ilmiah pola ini membuat matematika dapat dipelajari oleh setiap individu yang menumbuhkannya serta terbuka bagi perkembangan untuk konsep dan penemuan baru. Matematika juga merupakan salah satu ilmu yang berhubungan dengan angka-angka, lambing-lambang, mempunyai makna dan mempunyai antara lain tersendiri dalam menyelesaikan suatu masalah.

8 Damayanti dkk, "Perbandingan Kemampuan Representasi Matematis Siswa antara Contextual Teaching and Learning dan Problem Based Learning" JIPM (Jurnal Ilmiah Pendidikan Matematika), 7(1), 2018, h. 30-39. 
Matematika memiliki peranan yang sangat penting dalam kehidupan sehari-hari. Berbagai bentuk symbol matematis digunakan manusia sebagai alat bantu dalam perhitungan, penilaian, pengukuran, perencanaan, dan peramalan. Ilmu ini merupakan ilmu pengetahuan yang diperoleh dengan bernalar yang menggunakan istilah yang didefinisikan dengan cermat, jelas dan akurat, representasinya dengan lambing-lambang atau symbol dan memiliki arti serta dapat digunakan dalam pemecahan masalah yang berkaitan dengan bilangan.

Belajar materi matematika diharapkan siswa mampu mencapai suatu kompetensi yang telah ditetapkan. Hal itu merupakan gambaran karakteristik matematika sebagai suatu kegiatan manusia yang dikenal dengan sebutan mathematics as a human activity. ${ }^{9}$ Salah satu kompetensi matematis yang diharapkan di sekolah ialah siswa mampu memiliki kemampuan berpikir matematis. $^{10}$

Berpikir kreatif merupakan proses pembelajaran yang mengharuskan guru untuk dapat memotivasi dan memunculkan kreativitas siswa selama pembelajaran berlangsung, dengan menggunakan beberapa metode dan strategi yang bervariasi, misalnya kerja kelompok, bermain peran, dan pemecahan masalah. Dalam belajar matematika, siswa hendaknya memahami hubungan antara ide-ide matematis dan bidang studi lainnya. Ketika siswa telah mampu mengkreativitaskan beberapa ide matematis, maka siswa dapat memperoleh pemahaman yang lebih baik. Kemampuan berpikir kreatif matematis penting untuk dimiliki siswa dan perlu dilatihkan pada setiap siswa, jika siswa mampu mengaitkan ide-ide matematika maka kemampuan pemahaman matematisnya akan semakin baik dan lebih bertahan lama karena siswa mampu melihat kreativitas antar topik dalam matematika.

Proses belajar kreatif sebagai keterlibatan dengan sesuatu yang berarti, rasa ingin tahu dalam kegunaan, ketidak lengkapan, kekacauan, kerumitan, ketidak selarasan, ketidak teraturan dan sebagainya. Dengan demikian dalam belajar kreatif harus melibatkan komponen-komponen pengalaman belajar kreatif yang paling menyenangkan dan paling tidak menyenangkan lalu menemukan bahwa pengalaman dalam proses belajar kreatif sangat mungkin berbeda dengan pengalaman-pengalaman belajar yang sangat memberikan kepuasaan kepada kita dan sangat bernilai bagi kita.

Kemampuan berpikir kreatif merupakan kemampuan yang dikategorikan sebagai kemampuan berpikir tingkat tinggi atau High Order Thinking (HOT). HOT menjadi salah satu tujuan dari kurikulum 2013 yang harus dicapai oleh siswa. ${ }^{11}$ Kemampuan berpikir kreatif matematis merupakan kemampuan yang penting untuk dimiliki oleh seseorang. Akan tetapi nyatanya hasil belajar matematika siswa di sekolah belum menunjukan hasil yang menggembirakan, khususnya dalam aspek berpikir kreatif matematis.

Bahkan kebanyakan guru dan siswa lebih suka melaksakan memakai metode konvensional, ceramah atau memberikan tugas dari buku latihan kerja siswa yang tidak merangsang siswa untuk memiliki kemandirian belajar. Bila

9 Afriansyah, "Enhancing Mathematical Problem Posing via Realistic Approach" International Seminar on Mathematics, Science, and Computer Science Education MSCEIS, 2016.

${ }^{10}$ Afriansyah dkk, "The analysis of mathematics with ATLAS.ti", Journal of Physics: Conference Series 1402 (7), 2019, 077097.

${ }^{11}$ Gais dkk, "Analisis Kemampuan Siswa dalam Menyelesaikan Soal High Order Thinking Ditinjau dari Kemampuan Awal Matematis Siswa”, Mosharafa: Jurnal Pendidikan Matematika, 6(2), 2017, 255-266. 
upaya pengkondisian itu kurang mendukung pada pencerahan atau pengembangan penalaran serta keterampilan berpikir yang baik, maka akan melahirkan lulusan pendidikan yang kurang optimal.

Pada kenyataannya, memang ada manusia yang muncul sebagai pribadi yang kreatif dan ada yang kurang kreatif. Pribadi yang kreatif adalah individu yang mampu mengaktifkan potensi kreativitasnya. Hal itu bisa terjadi karena rangsangan lingkungan atau karena proses pembelajaran. Sementara mereka yang kurang mendapatkan lingkungan yang menantang atau kurang terkondisikan maka potensi kreatifitasnya tidak berkembang secara maksimal.

Orang yang berpikir adalah orang yang selalu ingin tahu, ingin mencobacoba, berperualang, serta intuitif dan mempunyai potensi untuk menjadi orang kreatif. Berpikir merupakan suatu kegiatan mental yang melibatkan kerja otak. Akan tetapi, pikiran manusia walaupun tidak bisa dipisahkan dari aktivitas kerja otak, lebih dari sekedar kerja organ tubuh. Biasanya kegiatan berpikir dimulai ketika muncul keraguan dan pertanyaan untuk dijawab atau berhadapan dengan persoalan atau masalah yang memerlukan pemecahan. Kegiatan berpikir juga dirangsang oleh kekaguman dan keheranan dengan apa yang terjadi atau dialami.

Orang yang kreatif merupakan kemampuan berpikir yang menciptakan sesuatu yang baru. Bahwa orang kreatif menggunakan pengetahuan yang dimiliki dan pengetahuan orang lain dan kemudian memperkuat terobosan atau lompatan yang memungkinkan mereka memandang segala sesuatu dengan cara yang baru yang belum mereka alami sebelumnya. Kecerdasan yang berkembang dalam diri individu, dalam bentuk sikap, kebiasaan, dan tindakan dalam melahirkan sesuatu yang baru dan oisinal untuk memecahkan masalah.

Berdasarkan pernyataan tersebut, kemampuan berpikir kreatif matematis penting untuk dimiliki siswa dan perlu dilatihkan pada setiap siswa, jika siswa mampu mengaitkan ide-ide matematika maka kemampuan pemahaman matematisnya akan semakin baik dan lebih bertahan lama, karena siswa mampu melihat kreativitas antar topik dalam matematika. ${ }^{12}$

Rendahnya kemampuan berpikir kreatif disebabkan oleh proses pembelajaran matematika yang masih cenderung monoton dan terlalu memaksakan cara berpikir yang dimiliki gurunya. Akibat dari pembelajaran tersebut, siswa bersikap pasif, hanya mencontoh apa yang guru kerjakan, tanpa memahami maknanya. ${ }^{13}$ Penyebab rendahnya kemampuan berpikir kreatif matematis siswa dalam pembelajaran matematika diantaranya karena proses pembelajaran yang belum optimal. Selain itu banyak guru yang kurang memperlihatkan penggunaan konteks yang bersumber dunia nyata, padahal konteks dapat membangkitkan pengetahuan dan keterampilan siswa melalui pengalaman nyata. Sehingga siswa sulit mengaplikasikan pengetahuan mereka dalam matematika ke dalam kehidupan nyata.

Proses pembelajaran yang belum optimal inilah yang harus coba diperbaiki agar dapat mencapai tujuan yang diinginkan. Proses pembelajaran yang guru gunakan haruslah menjadi jalan terciptanya proses pembelajaran yang

${ }^{12}$ Rahmi, "Realistic Mathematics Education: Model Alternatif Pembelajaran Matematika Sekolah", JKPM IAIN, 1(2), 2015, 3-5.

13 Novi, "Pengaruh Model Pembelajaran Missouri Mathematics terhadap Kemampuan Berpikir Kreatif Siswa", Jurnal Pendidikan Matematika Universitas Indraprasta PGRI Jakarta, 2016. 
optimal. $^{14}$ Media pembelajaran dipandang menjadi alternatif penyelesaian masalah pembelajaran dikelas. Dengan memanfaatkan media pembelajaran, kemampuan berpikir kreatif pada pelajaran matematika menjadi meningkat dan membantu guru dalam mengatasi kesulitan siswa.

Selain dengan berbantuan media pembelajaran, peningkatan kemampuan berpikir kreatif siswa dapat dicapai melalui education game. Hal tersebut dapat meningkatkan pola pikir kreatif serta menambah pengetahuan dan hasil belajar siswa.

Berpikir kreatif merupakan ungkapan dari keunikan individual dalam interaksi dengan lingkungannya. Ungkapan kreatif inilah yang mencerminkan orisinalitas dari individu tersebut. Dari ungkapan pribadi yang unik dapat diharapkan timbulnya ide-ide dan kualitas karya pribadi, mampu menciptakan suatu gagasan baru. Berpikir kreatif harus memenuhi tiga syarat, antara lain :

1) Kreativitas melibatkan respon atau gagasan yang baru,

2) Memecahkan persoalan secara realistis,

3) Kreativitas merupakan usaha untuk mempertahankan in-sight yang orisinil, menilai dan mengembangkannya sebaik mungkin.

Kecerdasan merupakan ungkapan dari cara berpikir seseorang yang dapat dijadikan modalitas belajar, hampir semua orang cenderung pada slah satu modalitas belajar yang berperan sebagai saringan untuk pembelajaran, pemprosesan dan komunikasi. Kecerdasan juga merupakan keseluruhan kemampuan individu untuk berpikir dan bertindak secara terarah, menyelesaikan suatu masalah, memperoleh pengetahuan, mengolah dan menguasai lingkungan secara efektif, serta menggunakan pengalaman masa lalu untuk mewujudkan suatu perubahan dalam diri kea rah yang lebih baik.

Kecerdasan merupakan upaya pengalaman belajar yang dilakukan dalam kehidupan sehari-hari serta kemampuan memecahkan sebuah permasalahan yang dialami. Permasalahan-permasalahan tersebut berasal dari dalam diri individu, permasalahan social, permasalahan akademik, kultural, serta permasalahan ekonomi keluarga. Kecerdasan seseorang dapat dilihat dari beberapa faktor yaitu faktor pembawaan, kematangan, pembentukan, minat dan pembawaan yang khas dan kebebasan.

Kecerdasan intrapersonal merupakan kecerdasan menganalisis diri dan merenungkan dalam kesunyian dan menilai prestasi seseorang dengan perasaan yang terdalam. Kecerdasan ini melibatkan kemampuan untuk memahami diri sendiri. Kecerdasan ini menunjukkan kemampuan seseorang untuk peka terhadap perasaan dirinya sendiri. Kecerdasan ini cenderung mampu untuk mengenali berbagai kekuatan maupun kelemahan yang ada pada dirinya sendiri. Orang semacam ini senang melakukan intropeksi diri, mengoreksi kekurangan maupun kelemahannya, kemudian mencoba untuk memperbaiki diri. Beberapa diantaranya cenderung menyukai kesunyian dan kesendirian, merenung dan berdialog dengan dirinya sendiri.

Siswa yang memiliki kecerdasan Intrapersonal yang tinggi akan mampu memahami kemampuan dirinya sendiri dan bersifat mandiri, mereka akan menemukan cara belajar mereka sendiri. Oleh karena itu komunikasi yang dilakukan oleh siswa dengan kecerdasan Intrapersonal yang tinggi biasa

${ }^{14}$ Luritawaty, "Pengembangan Kemampuan Komunikasi Matematik melalui Pembelajaran Take and Give", Mosharafa: Jurnal Pendidikan Matematika, 8(2), 2019, 239-248. 
dituangkan dalam bentuk tulisan, cenderung pasif dalam berbicara, dalam hal ini kemampuan komunikasi lisannya kurang. ${ }^{15}$

cara meningkatkan kecerdasan yaitu dengan cara :

1) Memilih tokoh favorit yang positif dan baca serta jadikan mereka sebagai kawan imajinasi dalam memecahkan suatu permasalahan yang membutuhkan waktu pemahaman yang dalam,

2) Melakukan sesuatu yang menyenangkan diri sekurang-kurangnya sekali sehari,

3) Meluangkan waktu sekitar 10 menit setiap sore hari untuk meninjau kembali secara mental berbagai macam perasaan dan gagasan yang dialami.

Kecerdasan intrapersonal merupakan kecerdasan yang berhubungan dengan kesadaran dan pengetahuan tentang diri sendiri, yang melibatkan kemampuan untuk secara tepat dan nyata menciptakan gambaran mengenai diri sendiri. Cara mengembangkan kecerdasan intrapersonal pada peserta didik yaitu :

1) Menciptakan citra diri positif,

2) Menciptakan suasana yang mendukung perkembangan kemampuan intrapersonal dan penghargaan diri anak,

3) Menuangkan isi hati dalam jurnal pribadi,

4) Bercakap-cakap tentang minat dan keadaan diri anak,

5) Memberikan kesempatan menggambarkan diri sendiri dari sudut pandang anak,

6) Membayangkan diri dimasa yang akan dating,

7) Mengajak berimajinasi jadi satu tokoh sebuah cerita.

Belajar merupakan kewajiban bagi setiap orang dalam rangka memperoleh ilmu pengetahuan sehingga derajat kehidupannya meningkat. Belajar merupakan proses yang dilakukan oleh indivisu untuk memperoleh sebuah perubahan tingkah laku yang menetap, baik yang dapat diamati maupun yang tidak dapat diamati secara langsung, yang terjadi sebagai suatu hasil latihan atau pengalaman dalam interaksinya dalam lingkungannya.

Mandiri akan muncul bila seseorang belajar, dan sebaliknya kemandirian tidak akan muncul dengan sendirinya bila seseorang tidak mau belajar. Terlebih lagi kemandirian dalam belajar tidak akan muncul apabila siswa tidak dibekali dengan ilmu yang cukup. Kemandirian dalam belajar merupakan keharusan dan tuntutan dalam pendidikan saat ini. Kemandirian adalah individu yang mampu menghadapi masalah-masalah yang dihadapinya dan mampu bertindak secara dewasa. Ciri utama belajar mandiri adalah adanya pengembangan kemampuan siswa untuk melakukan proses belajar yang tidak tergantung pada faktor guru, teman, kelas dan lain-lain. Tingkat kemandirian belajar siswa dapat ditentukan berdasarkan seberapa besar inisiatif dan tanggung jawab siswa untuk berperan aktif dalam hal perencanaan belajar, proses belajar maupun evaluasi belajar. Semakin besar peran aktif siswa dalam berbagai kegiatan tersebut, mengindikasikan bahwa siswa tersebut memiliki tingkat kemandirian belajar yang tinggi.

Kemandirian belajar merupakan suatu usaha yang dilakukan dalam aktivitas belajar dengan cara mandiri atas dasar motivasinya sendiri dalam menguasai suatu materi tertentu sehingga dapat digunakan dalam memecahkan

15 Nisa dkk, "Yurisdiksi Kriminal Terhadap Black Flight Di Ruang Udara Wilayah Indonesia” SASI, 26(3), 2020, 365-379. 
masalah yang dihadapi. ${ }^{16}$ Kemandirian belajar merupakan kemampuan yang dimiliki oleh siswa dalam melakukan kegiatan pembelajaran dengan dorongan sendiri serta tanpa adanya paksaan. ${ }^{17}$

Kemandirian belajar didasarkan atas pemahaman terhadap potensi diri. Pemahaman ini mendasar menjalani proses kehidupannya. Kemandirian belajar siswa dibentuk dari ide yang ia kembangkan dan dibangun berdasarkan pengolahan informasi yang ia dapat tentang dirinya. Kemampuan kemandirian belajar matematika juga penting yang harus dimiliki seorang siswa. Banyak siswa yang memiliki kemampuan kemandirian yang cukup rendah akibatnya proses pembelajaran tidak dapat tercapai sesuai dengan apa yang ditargetkan. Apabila kemampuan kemandirian belajar tidak terpenuhi maka suatu pembelajaranpun tidak akan terlaksana dengan baik.

Terdapat delapan ciri kemandirian belajar, yaitu:

1) Mampu berfikir secara kritis, kreatif dan inovatif;

2) Tidak mudah terpengaruh oleh pendapat orang lain;

3) Tidak lari atau menghindari masalah;

4) Memecahkan masalah dengan berfikir yang mendalam;

5) Apabila menjumpai masalah dipecahkan sendiri tanpa meminta bantuan orang lain;

6) Tidak merasa rendah diri apabila harus berbeda dengan orang lain;

7) Berusaha bekerja dengan penuh ketekunan dan kedisiplinan; serta

8) Bertanggung jawab atas tindakannya sendiri. ${ }^{18}$

Menyadari akan pentingnya kemandirian belajar mahasiswa terlebih di perguruan tinggi, maka harus diupayakan pembelajaran dengan menerapkan pembelajaran yang bisa melibatkan mahasiswa secara penuh dalam proses pembelajaran, mendorong mahasiswa mampu menyusun sendiri pengetahuannya, menemukan materi yang dipelajari dan menghubungkannya dengan situasi kehidupan nyata sehingga mereka dapat menerapkannya dalam kehidupan seharihari, dapat berpikir kreatif dan inovatif serta rasional.

Masyarakat modern yang berkembang pesat membutuhkan individu yang memiliki kemampuan untuk berpikir, bertindak, dan berkomunikasi secara kreatif. Kreatifitas mahasiswa atau mahasiswa 69 dibangun melalui pembelajaran yang dimulai dengan menekankan aspek kemandirian. ${ }^{19}$

Kemandirian belajar sebagai bagian penting dalam pendidikan karakter sangat penting untuk diwujudkan karena pembelajaran era sekarang sudah bergeser dari paradigma "teacher centered" kepada "student centered". Kemandirian belajar merupakan aktivitas belajar yang dilakukan siswa tanpa bergantung kepada bantuan dari orang lain baik teman maupun gurunya dalam mencapai tujuan belajar yaitu menguasai materi atau pengetahuan dengan baik dengan kesadarannya sendiri serta dapat mengaplikasikan pengetahuannya dalam

\footnotetext{
${ }^{16}$ Egok, asep sukenda, "Kemampuan berpikir kritis dan kemandirian belajar dengan hasil belajar matematika”, Jurnal Pendidikan Dasar UNJ, 7(2), 2017, h. 186-199.

${ }^{17}$ Bungsu, "Pengaruh kemandirian belajar terhadap hasil belajar matematika di SMKN 1 cihampelas", Journal On, 01(02), 2019, h. 382-389.

18 Sundayana, "Kaitan Antara Gaya Belajar, Kemandirian Belajar, Dan Kemampuan Pemecahan Masalah Siswa SMP Dalam Pelajaran Matematika” Mosharafa. Vol. 5, No. 2, 2017, h. 75-84.

${ }^{19}$ Wijaya, "How do open-ended problems promote mathematical creativity? A reflection of bare mathematics problem and contextual problem", Journal of Physics: Conf. Series 983 (2018) 012114.
} 
menyelesaikan masalah-masalah dalam kehidupan sehari-hari. Kemandirian belajar yang dipadukan dengan keaktifan mahasiswa untuk menunjang proses pembelajaran sangatlah bergantung pada kondisi saat ini. Tumbuhnya kemandirian belajar mahasiswa diwujudkan dalam bentuk meningkatnya keyakinan diri. Berkaitan dengan keyakinan diri sebagai indikator kemandirian belajar.

Kemandirian belajar sendiri diartikan sebagai sifat, kemauan, dan kemampuan siswa untuk melakukan kegiatan belajar aktif yang didorong oleh motivasi untuk menguasai sesuatu kompetensi yang tetah ditetapkan. Indikator dalam kemandirian belajar yaitu inisiatif belajar, mendiagnosa kebutuhan belajar, menetapkan target serta tujuan belajar, memonitor, mengatur, serta mengontrol, memandang kesulitan sebagai tantangan, memanfaatkan serta mencari sumber relavan, memilih serta menerapkan strategi belajar, mengevaluasi proses dan hasil belajar serta self efficacy atau konsep diri.

Terdapat 6 ndikator kemandirian belajar diantaranya ketidaktergantungan terhadap orang lain, memiliki kepercayaan diri, berperilaku disiplin, memiliki rasa tanggung jawab, berperilaku berdasarkan inisiatif sendiri serta melakukan kontrol diri. $^{20}$ Terdapat 8 indikator kemandirian belajar diantaranya berinisiatif, merancang kebutuhan belajar, menetapkan tujuan, menetapkan strategi, menganggap kesulitan sebagai tantangan, mencari dan memanfaatkan sumber belajar yang dibutuhkan, mengontrol proses serta mengevaluasi hasil belajar serta kemampuan mengatur diri sendiri. ${ }^{21}$

Dari beberapa pernyataan tersebut dapat disimpulkan bahwa indikator kemandirian belajar siswa diantaranya memiliki kepercayaan diri, mempunyai sikap disiplin, memiliki rasa tanggung jawab, memiliki inisiatif sendiri, mempunyai rencana dalam belajar, memecahkan masalah dengan keinginan sendiri, berpartisipasi aktif, memiliki keinginan untuk maju

Berdasarkan konsep dan teori yang sudah dijelaskan diatas, dikatakan bahwa kemandirian dalah kebebasan dari pengaruh orang lain sehingga mampu berbuat, bertindak, dan berfikir atas dasar kreatif dan penuh inisiatif, percaya diri, bertanggung jawab serta mampu mengatasi problem yang dihadapi dan melakukan hal ynag menurutnya baik atas integritas dirinya. Kemandirian belajar dalam penelitian ini merupakan perilaku siswa dalam mewujudkan keinginan atau kehendaknya secara nyata dengan tidak bergantung pada orang lain serta mampu mempertanggung jawabkan tindakannya. Dalam hal ini siswa mampu melakukan belajar sendiri, dapat menentukan cara belajar yang efektif, mampu melakukan tugas-tugas belajar dengan baik dan mampu untuk melakukan aktivitas belajar secara mandiri.

Penelitian ini dilaksanakan di MTs Swasta Kabupaten Serang. Kegiatan ini melibatkan tiga sekolah yaitu MTs Nurul Falah Pasanggrahan, MTs Nur El Falah Kubang dan MTs Nurul Falah Cigodeg kelas VIII. Metode yang digunakan dalam penelitian ini adalah metode survey yaitu pengamatan atau penyelidikan yang kritis untuk mendapatkan keterangan yang terang dan baik terhadap suatu persoalan tertentu dan didalam suatu daerah tertentu. Tekhnik sampling yang

${ }^{20}$ Diana dkk, "Blended learning dalam pembentukan kemandirian belajar", Alinea: Jurnal Bahasa Sastra Dan Pengajaran, 9(1), 2020, 16-22.

${ }^{21}$ Subekti dkk, "Peningkatan Kemampuan Pemecahan Masalah dan Kemandirian Belajar Mahasiswa Melalui Pembelajaran Berbasis Masalah", JNPM (Jurnal Nasional Pendidikan Matematika), 4(1), 2020, 13-27. 
dih=gunakan adalah multi stage sampling. Tekhnik ini merupakan teknik kombinasi beberapa teknik sampling yang ada. Dengan teknik ini peneliti mudah memperoleh data dari subjek yang diinginkan.

Untuk memperoleh data tentang kemampuan berpikir kreatif pada matematika, peneliti melakukan survey terhadap siswa dengan memberikan instrument berupa soal berbentuk essay. Data kecerdasan intrapersonal dan kemandirian belajar dengan memberikan instrument non tes berupa skala sikap. Berdasarkan hasil penelitian bahwa peningkatan kemampuan berpikir kreatif dapat dilakukan dengan peningkatan kemandirian belajar yang lebih baik. Dan mpeningkatan kemampuan berpikir kreatif oleh kecerdasan intrapersonal melalui kemandirian belajar lebih tinggi dari pada kecerdasan intrapersonal.

\section{KESIMPULAN}

Berdasarkan hasil analisis dan pengujian hipotesis terhadap hasil penelitian pengaruh kecerdasan intrapersonal dan kemandirian belajar terhadap kemampuan berpikir kreatif pada pelajaran matematika diperoleh kesimpulan sebagai berikut :

1) Terdapat pengaruh langsung yang signifikan kecerdasan intrapersonal terhadap kemampuan berpikir kreatif pada pelajaran matematika.

2) Terdapat pengaruh langsung yang signifikan kemandirian belajar terhadap kemampuan berpikir kreatif pada pelajaran matematika.

3) Terdapat pengaruh langsung yang signifikan kecerdasan intrapersonal terhadap kemandirian belajar.

4) Terdapat pengaruh tidak langsung yang tidak signifikan kecerdasan intrapersonal terhadap kemampuan berpikir kreatif siswa melalui kemandirian belajar siswa.

Hal ini menunjukkan bahwa akan lebih efektif meningkatkan kemampuan berpikir kreatif dilakukan dengan membangkitkan kemandirian belajarnya terlebih dahulu pada mata pelajaran matematika. Sehingga siswa mudah menangkap materi yang diajarkan dan siswa akan lebih termotivasi serta senang dalam belajar karena sudah terbiasa dengan system pembelajarannya.

\section{DAFTAR PUSTAKA}

Afriansyah, E. A. (2016). Enhancing Mathematical Problem Posing via Realistic Approach. International Seminar on Mathematics, Science, and Computer Science Education MSCEIS.

Afriansyah, E.A., Puspitasari, N., Luritawaty, I., Mardiani, D., \& Sundayana, R. (2019). The analysis of mathematics with ATLAS.ti. Journal of Physics: Conference Series 1402 (7), 077097.

Bungsu, T. K., Vilardi, M., Akbar, P., \& Bernard, M. (2019). pengaruh kemandirian belajar terhadap hasil belajar matematika di SMKN 1 cihampelas. Journal On, 01(02), 382-389.

Damayanti, R., \& Afriansyah, E. A. (2018). Perbandingan Kemampuan Representasi Matematis Siswa antara Contextual Teaching and Learning dan Problem Based Learning. JIPM (Jurnal Ilmiah Pendidikan Matematika), 7(1), 30-39.

Diana, P. Z., Wirawati, D., \& Rosalia, S. (2020). blended learning dalam pembentukan kemandirian belajar. Alinea: Jurnal Bahasa Sastra Dan Pengajaran, 9(1), 16-22. 
Egok, asep sukenda. (2017). kemampuan berpikir kritis dan kemandirian belajar dengan hasil belajar matematika. Jurnal Pendidikan Dasar UNJ, 7(2), 186199.

Fajriyah dan Supardi. 2015. Penerapan Strategi Pembelajaran Metakognitif terhadap Hasil Belajar Matematika. Edu Research, Vol. 1:169-195. Jakarta: Unindra Press.

Fajriyah, L., Nugraha, Y., Akbar, P., \& Bernard, M. (2019). Pengaruh kemandirian belajar siswa smp terhadap kemampuan penalaran matematis. Journal On Education, 01(02), 288-296.

Gais, Z., \& Afriansyah, E. A. (2017). Analisis Kemampuan Siswa dalam Menyelesaikan Soal High Order Thinking Ditinjau dari Kemampuan Awal Matematis Siswa. Mosharafa: Jurnal Pendidikan Matematika, 6(2), 255266.

Hanipah, N., Yuliani, A., \& Maya, R. (2018). Analisis Kemampuan Berpikir Kreatif Matematis Siswa MTs Pada Materi Lingkaran. AKSIOMA: Jurnal Program Studi Pendidikan Matematika, 7(1).

Luritawaty, I. P. (2019). Pengembangan Kemampuan Komunikasi Matematik melalui Pembelajaran Take and Give. Mosharafa: Jurnal Pendidikan Matematika, 8(2), 239-248.

Maharani, A. (2017). Analisis Pengembangan Soal Tes Evaluasi Matematika Berbasis Kemampuan Berpikir Kreatif Untuk Siswa SMK pad Materi Geometri. AKSIOMA: Jurnal Program Studi Pendidikan Matematika, 6(3).

Muhammad Wadji, Andi Asmawati Aziz, dan Rosdiana Ngitung. 2018. "Hubungan Kecerdasan Naturalistik, Kecerdasan Interpersonal, dan Kecerdasan Intrapersonal dengan Hasil Belajar Biologi Siswa Kelas XI IPA SMA Negeri di Kota Makasar", UNM Journal of Biological Education, Vol-2 (1).

Munahefi, D. N., Waluya, S. B., \& Rochmad. (2018). Analysis of Creative Mathematic Thinking Ability in Problem Based Learning Model Based on Self- Regulation Learning. Journal of Physics: Conference Series, 983(1), $1-5$.

Nisa, C. U., \& Disemadi, H. S. (2020). Yurisdiksi Kriminal Terhadap Black Flight Di Ruang Udara Wilayah Indonesia. SASI, 26(3), 365-379.

Novi. (2016). Pengaruh Model Pembelajaran Missouri Mathematics terhadap Kemampuan Berpikir Kreatif Siswa. Jurnal Pendidikan Matematika Universitas Indraprasta PGRI Jakarta.

Rahmi, I. (2015). Realistic Mathematics Education: Model Alternatif Pembelajaran Matematika Sekolah. JKPM IAIN, 1(2), 3-5.

Subekti, F. E., \& Jazuli, A. (2020). Peningkatan Kemampuan Pemecahan Masalah dan Kemandirian Belajar Mahasiswa Melalui Pembelajaran Berbasis Masalah. JNPM (Jurnal Nasional Pendidikan Matematika), 4(1), 13-27.

Sundayana, R. (2016). Kaitan Antara Gaya Belajar, Kemandirian Belajar, Dan Kemampuan Pemecahan Masalah Siswa SMP Dalam Pelajaran Matematika. Mosharafa. Vol. 5, No. 2 Hal. 75-84.

Syasmita I, D. Setiawan, D. Saragi. 2019. The Influence of Ethno Pedagogy Approach and Interpersonal Intelligence on the Results of Civic Education Learning in Pelangi Elementary school Medan. BirLE Journal. 2 (4): 603 615. 
Wijaya, A. (2018). How do open-ended problems promote mathematical creativity? A reflection of bare mathematics problem and contextual problem. Journal of Physics: Conf. Series 983 (2018) 012114, International Conference on Mathematics, Science and Edu tion 2017 (ICMSE2017). 